\title{
Research on Ideological and Political Education under New Media Technology Background
}

\author{
Yanying $\mathrm{Di}^{1, \mathrm{a}}$ \\ Jilin Agricultural Science and Technology University, 132101, Jilin City, China
}

Keywords: New media, ideological and political education, dynamic and static display, college students

\begin{abstract}
With the rapid development of information technology, to blog, instant messaging tools, and streaming media as the main indicator of new media technology to the current ideological and political education with great effect. In this paper, ideological and political education systems was established by the Propaganda Department, Student Affairs, Network Information Centre and other departments working mechanism of interaction. Strengthen ideological and political education, team building, also under the new media, ideological and political education, an important step.
\end{abstract}

\section{Introduction}

The new media is relative to the traditional media, it will never end on a fixed media forms the rapid development of information technology is growing at an unprecedented breadth and depth of the impact of the economic and social development, in order. Blog, instant messaging and streaming media tools as the main indicator of new media technology to the current ideological and political education has brought increasingly profound impact. " On the one hand, it gives ideological and political education has posed a serious challenge, "it makes the ideological and political education environment has become more complex, the work object model, the team under attack; on the other hand," the rapid development of new media technologies also ideological and political education of college students brought a rare opportunity. The spread of new media technologies for its convenience, mass information and other advantages to expand the content and space ideological and political education, enrich the means and methods of ideological and political education, and the pertinence and effectiveness of ideological and political education has been enhanced.

Thus, "the ideological and political education of college students under the new media technology background research, can effectively solve the current difficulties and problems of ideological and political education of college students are facing further grasp the law of ideological and political education, while in favour of the rich ideological and political education theory, open up horizons of ideological and political education, in order to better guide the practice.

In recent years, with the rapid development of information technology, front-line workers, many domestic experts and scholars and ideological and political education to start thinking about the ideological and political education of college students under the new media technology background, with some preliminary research. Mainly in the following aspects: First, the application of new media technology in some support for the representatives. Is to study the combination of new media technologies such as a carrier network, blog conducted such studies a lesser extent, to solve the problem is relatively narrow field of vision; the second is more focused on macro research, fewer microscopic study. It found that current research results more from the macro point of cut, more theoretical discourse, with practice is not deep enough, practical value is not high; third, throw more research problem, to solve the problem is relatively small.

In foreign countries, Europe and America, Japan and other countries of the University of new media technology and applications of great importance to start earlier, they attach great importance to the construction of social communication mechanisms in the construction of social communication mechanisms, many foreign practices reflects the subtle, focusing on infiltration and influence of education, the effect achieved is ideal. For example, "The United States attaches great importance to the ideological education of the integrity and consistency of environmental education. The US

a Corresponding author: yanyingdi001@126.com 
government every year or even tens of billions of dollars will be invested heavily in the media and publishing industry, they promote the spread of bourgeois values, It played an important role on the world view.

\section{Type New Media Technology}

New media technology from the form of expression can generally be divided into chat categories, display categories and forums classes. Chat class new media technology is based on individual chat as the main form, emphasizing the interactive communication between individuals, such as SMS, QQ, e-mail, MSN and so on. Display category new media technology is the use of network platform to some of the specific form of the carrier, through dynamic or static display, to achieve the purpose of communication and exchanges, such as blog, digital TV, Internet TV, portals.

Forum category of new media technology is based on the individual student as the basic unit, with the help of the network setup process, and gradually extended from the individual to a different unit classes, schools, and gradually form of mass communication platform. Such as campus network, QQ group, alumni, paste it, and other campus BBS, virtual community forum.

New media technology rapidly gaining popularity with its unique advantages, changing the way college students' learning, lifestyles and ways of thinking fundamentally. A variety of new media technologies generally have the following characteristics:

E-Mail, BBS, personal websites are all relatively early emergence of new media, information exchange, so that students can very well show themselves, to express themselves. Then there is also a blog can be more quickly and easily publish personalized information, creative, flexible and constructive, college students can make use of new technologies, freely publish personalized information through text, pictures, video and other forms to reflect a personal original ecology lives, thoughts and so on. In addition, college students can be face to face in the network accessibility, personal emotional language is more prone to proximity and identity, to narrow the distance between people. The characteristics of the new media to express themselves more easily to meet the internal needs of college students, college students this knowledge by groups of all ages and blitz.

Media and the traditional ideological and political education is different, most of the new media, the venue is not determined in the real environment, but in a virtual environment. This makes the new media technology operator who has occult, such as college students in the network can use the nickname, instead of a virtual ID, concealing the true identity. Uncertainty and identity of the subject of educational performance scenarios hide alleviate their mental alert, enhance the educational effect. In this situation, the two sides exchange minimizes the traditional face to face during the various possible confounders objective. At the same time, with the protective layer, college students can freely express remarks by the new media blog, forums, logging and other forms of participation in opinion, which meets college students' free association behaviour to a large extent.

New media technology on the way to achieve the expression of the nature of the spread of equality interactive, mainly for equity release information and opinions expressed. For example, regardless of status, anyone can easily apply through the new media technologies their own place in the virtual space, equal to express their views and opinions. Everybody is educated in an interview with the information, the information in the release time for the trainer, timely views on both interested in communication, communication, enhance the initiative and on the basis of two-way interaction, equality on . This duality of both subject knowledge, psychology and the competency of the body raised higher requirements, but also for effective communication between educators and educational objects communicate provide a psychological basis, to enhance the ideological and political education of the two-way, equality has laid a good foundation to improve educational efficiency.

The characteristics of the new media technology, the weekdays are generally acceptable for others to educate students, no doubt will gain a great sense of respect and satisfaction, and thus further stimulate the enthusiasm of their participation. New media technology to build up in the virtual world space can be stored for long periods at any time convenient for people to view your recorded 
bit by bit, comprehensive understanding of their mature the whole process. In addition, the "new media technology, information can be instantly transmitted, the Earth has become a village of narrow, shorten the distance of space, the psychological distance between people closer. This unbounded enables us to keep abreast of the situation Students received information, thereby greatly improve ideological and political education of relevance, effectiveness, timeliness and coverage.

Compared with the traditional means of education, the application of new media technology to transmit information with more timeliness, quickness. At present, more and more students mainly through the network to obtain the latest information, the traditional media propaganda advantage gradually lost; more and more people through the network chat, exchange, make calls, letters and other traditional Information unprecedented impact. On the efficiency of information transmission, the new media technology can mobilize students' participation in the activities of the enthusiasm, initiative. Therefore, educators should make full use of Internet and other new media technology, expanding originality, individuality E-Mail, BBS, personal websites are all relatively early emergence of new media, information exchange, so that students can show their good, selfexpression. Then there is also a blog can be more quickly and easily publish personalized information, creative, flexible and constructive, college students can make use of new technologies, freely publish personalized information through text, pictures, video and other forms to reflect a personal original ecology lives, thoughts and so on. In addition, college students can be face to face in the network accessibility, personal emotional language is more prone to proximity and identity, to narrow the distance between people. The characteristics of the new media to express themselves more easily to meet the internal needs of college students, college students this knowledge by groups of all ages and blitz.

\section{The challenges of New Media Technology on Ideological and Political Education}

"The new media technology is a new web tool, application and dissemination of information carrier mode network environment, since the end of the century, with its unique mode of transmission have developed rapidly. At present, the" new media has become college students receive information, express feelings, an important platform to show themselves, and with unprecedented breadth and depth involved in the ideological and spiritual world, fundamentally changing the way college students' learning, lifestyles and ways of thinking, to the ideological and political education of college students brought increasingly profound impact. Wide application of new media technology to ideological and political education of college students presented a new challenge, the challenge is mainly manifested in the following aspects:

"In the new media age, the information transmitted in a 'No barriers', 'space without barriers', 'information without barriers', etc., information dissemination and the use of more freedom, and it is difficult to monitor, irresponsible, negative and backward ideological and culture and even antisocialist rhetoric widespread use of new media technologies, the impact of our culture theme, to the ideological and political work has brought great impact and difficulties. "The so-called ideological and political education environment, ideological and political education is facing around the subject around educational subjects and their impact on the objective reality. With the development of computer science and technology, new media, college students should receive a great deal of popularity, becoming an indispensable tool for studying and living on campus has become a new media culture and its surrounds the college students an important impact on the educational environment . However, the new information-pervasive media, new media campus culture may also bring some obvious ideological propensity to disseminate bourgeois mainstream culture for the purpose of "colonial culture", as well as immoral, unhealthy thoughts, the formation of a some of the ideological and political education unfavorable educational environment.

On the information highway has a wealth of useful health information, but there are no objective, scientific, decadent wrong things. On the one hand, new media, especially English is the main language of the Internet, the US-led Western countries by means of language, relying on its 
economic and technological superiority brazenly to other countries, particularly developing countries, with a clear tendency to spread the ideological content, giving teen Students instill the wrong political views and ideas; on the other hand, some domestic anti-socialist anti-evil people of the country using new media to disseminate information revolution, abetting confuse teenagers astray, such as "Falungong" cult has been on the network virus wanton dissemination of ideas, and if some of the separatists against the reunification of the motherland through the new media to promote "Taiwan independence ideology", "Tibetan separatist ideology"; in addition, "the new media can spread through the campus pornography, violence, murder and other information, bring some immoral unhealthy thoughts, these are all stained the campus new media environment in which the ideological and political education environment is complicated. Every one of us are more or less being affected our main activities in which the spirit of the environmental impact. "young college students are in the formative years of life, world outlook and values, thought extreme, full of curiosity about new things, it is susceptible to the environment, how to respond to environmental changes in the ideological and political education process, while avoiding disadvantages It has become a serious problem.

\section{New Media Technology to Ideological and Political Education Opportunities}

"The new media technology is the product of a new era for college students accepted, while also providing a rare opportunity for us to carry out ideological and political education." Dissemination of new media technologies for its convenience, mass information and other advantages to expand the ideological and political education content and space to enrich the means and methods of ideological and political education, and the pertinence and effectiveness of ideological and political education has been enhanced. "Process of College Students' ideological and political education, is access to information, choice, the process of communication, with rich, accurate, vivid information, influence, process ideas influence college students, values and mental state.

"The new media newspapers, radio, television appearances, with the dissemination of information in a timely manner, a large, interactive and other advantages, timeliness strong, continuous flow reports, widely Jina relevant information, provide information on a variety of forms, having three other media incomparable advantages Thus, the new media culture on campus greatly enriched the educational resources: a study of Marxism, Mao Zedong Thought, Deng Xiaoping theory and the important thought of "three Represents" provides a new platform; two to understand the offer party's line, principles and policies of the inexhaustible sources of information, such as Shandong University, through the campus network construction, domestic hot timely reports, focus information, both for the students to read the books of sages, and worried world It does provide a good platform; three for the spread of socialist culture and mainstream values expand the useful space "can be selected for educators in terms of a lot of information in a targeted, persuasive, the latest information, as education. Material. "For the purposes of the educated to understand a lot of information to form a comprehensive understanding to prevent touch with reality, ignorant.

\section{The Application of Multimedia Educational Technology of College Ideological and Political Education Evaluation System}

As mentioned earlier, in the mountains affected by the examination-oriented education, there is a tradition of sports evaluation system of education problems, its negative impact is obvious. To protect five [Ideological and political Education Reform without departing from the culture complex, the direction of innovative talents era of knowledge economy needs to ensure all-round development of the individual, promote and deepen the College Ideological and political Education Reform, we must build a line with our ideological and political education actual current university, with the correct orientation, workable science of ideological and political education evaluation system.

Establishing scientific evaluation system of ideological and political education of basic requirements: quality education as the core, and implement the guiding ideology of lifelong sports. 
Quality education is the national education policy based on "Education Law" provisions, aimed at the educated and long-term social development requirements in order for all students, and comprehensively improve the basic quality of students as the fundamental purpose, to focus on training the educated attitude, the ability to promote their lively development in moral, intellectual, ideological and political education and other basic features. Therefore, to establish a scientific evaluation system of sports education process, always grasp the core of quality education, not only to pay attention to students 'basic knowledge of sports, basic skills, basic skills to grasp the situation, but also concerned about the students' ideological and political ability (ability to self-exercise, the ability to self-evaluation, self-adaptive capacity), sports consciousness, sports habits and ideological and political behavior. Social development needs and individual development needs as the standard.

\section{Conclusion}

In this paper, literature, expert interview, system analysis and comparative studies and other research methods combined with practical work experience, present situation of Ideological and political Education in Colleges and Universities and the application of multimedia educational technology and deepening the necessity and feasibility of Ideological and political Education reform will be analysis, especially on how the application of multimedia educational technology deepening Ideological and political Education reform put forward some countermeasures and suggestions, the study reached the following conclusions:

Although the College Ideological and political Education Reform has been carried out for many years, but in the background of knowledge economy, the problem still exists behind the teaching model, faculty structure is irrational, the lack of venues and equipment, poor management, lack of theoretical teaching hours so not suited talents.

The application of multimedia educational technology can promote the transformation of higher education concept sports, speed up transformation of Ideological and political Education contents, improved teaching methods, educational principal role of conversion, optimization and improve the educational environment of educational evaluation system.

The application of multimedia educational technology is an important means to improve the quality of college ideological and political education, ideological and political education is the main way to achieve the multimedia of universities, but also a powerful tool for the promotion of Ideological and political Education for Sustainable Development. The development of multimedia educational technology in hardware technology, software technology and latent element technology for the multimedia educational technology Deepening Reform of Ideological and political Education to provide scientific and technical support.

Application of Multimedia Educational Technology to Enhancing Ideological and political Education reform should deal with the hardware, and the relationship between software; the relationship between multimedia educational media and traditional media, education; the relationship between multimedia educational technology and educational content between.

In the specific embodiment, by constructing a multimedia presentation based, interactive, individualized or virtual reality of new teaching models, establish and improve the college sports education management information system, the reconstruction of a Scientific PE evaluation system for education, building distinctive campus sports culture Home and other ways, active development of the times to meet the challenges of college ideological and political education to meet the needs of social development of innovative, interdisciplinary talents' training.

\section{References}

1. Wang and students, Shou Tao efforts to leverage the Party Building in Students' Political Education in Higher Education Forum, 2006, (4): 65-66.

2. Li Wei strengthening and improving ideological and political education of college students countermeasure Economist, 2006, (03): 32-35. 
3. WEI Xiao-Hui, Sun Zhiping Measures to strengthen and improve ideological and political education of graduate studies Jiamusi large Social Science Journal, 2006, (02): 9-11.

4. Wen Fengyuan graduate ideological and political education theory, 2006, (07): 56-59.

5. Zhou Lei, Wu Mian super counselor: the cornerstone of ideological and political education of Liaoning Administration College, 2007, (02): 9-10.

6. Guxiu Ping Role of Multimedia Educational Technology in the Teaching of College Sports. Nanjing Institute of Technology, 3 (2004).

7. From Liu Mei, Tao Yun III. Influence of Multimedia Educational Technology on College Ideological and political Education in Anhui electronic information Vocational and Technical College, 32 (2005).

8. Tao Yun three Jiayi Zheng Multimedia Educational Technology in College Sports Teaching Problems and Countermeasures of Anhui Technical Teachers College, 19 (2005). 